\begin{tabular}{|c|c|c|}
\hline & Int.J.Curr.Microbiol.App.Sci (2016) 5(4): 140-158 & \multirow{4}{*}{ 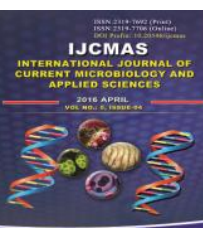 } \\
\hline & \multirow{4}{*}{$\begin{array}{l}\text { International Journal of Current Microbiology and Applied Sciences } \\
\text { ISSN: 2319-7706 Volume } 5 \text { Number } 4 \text { (2016) pp. 140-158 } \\
\text { Journal homepage: http://www.ijcmas.com }\end{array}$} & \\
\hline & & \\
\hline & & \\
\hline PUBLISHERS & & www ijemas.com \\
\hline
\end{tabular}

Original Research Article

http://dx.doi.org/10.20546/ijcmas.2016.504.019

\title{
A Study of Virulence Factors and Drug Resistance Pattern in Escherichia coli Isolated from Extra Intestinal Infections in a Tertiary Care Teaching Hospital, Chinakakani, Guntur, Andhra Pradesh, South India
}

\author{
Anuradha Bhrugubalda, Uma Penmetcha*, Padmaja Yarlagadda and \\ Ramesh Babu Myeneni \\ Department of Microbiology, NRI Medical College and General Hospital, Chinakakani \\ Mangalagiri Mandal, Guntur District, Andhra Pradesh, India - 522503. \\ *Corresponding author
}

\section{Keywords \\ Escherichia coli, Haemolysin, Serum resistance, MSHA \& MRHA, Cell surface hydrophobicity, Gelatinase, ESBL.}

\begin{tabular}{l}
\hline Article Info \\
\hline \\
Accepted: \\
14 March 2016 \\
Available Online: \\
10 April 2016 \\
\end{tabular}

\section{A B S T R A C T}

E. coli is one of the most common pathogen that could be isolated from intestinal and from many extra intestinal infections. They can cause extra intestinal infections in both community and hospitalised patients. These extra intestinal pathogenic Escherichia coli strains exhibit certain virulence factors. The present study was undertaken to know the incidence of Escherichia coli in symptomatic cases of extra intestinal infection, to detect the virulence factors of extra intestinal pathogenic E.coli\& to know the antimicrobial susceptibility pattern of extra intestinal Escherichia coli isolates. A total of 100 clinical isolates of extra intestinal E.coli and 25 commensal E.coli isolated from apparently healthy individual were screened for virulence factors like cell surface hydrophobicity, haemolysin production, Serum resistance, Mannose resistant haemagglutination (MRHA) and gelatinase production by standard methods. Chi square test was used to analyse the result. Of the 100 Extra intestinal E.coli $51 \%$ of isolates showed serum resistance. Hemolysin was produced by $47 \%$. 23\% showed cell surface hydrophobicity, $20 \%$ were MRHA positive \& only 2 isolates produced protease. All the four virulence factors were present in $13 \%$ of isolates. Statistically significant difference was observed for haemolysin production \& statistically highly significant difference was observed for cell surface hydrophobicity \&haemagglutination activity $(\mathrm{P}<0.01$ and $\mathrm{P}=0.001$ ). Majority, $91 \%$ of E.coli isolates were sensitive to amikacin and 70 to $99 \%$ were resistant to ciprofloxacin \& ampicillin. ESBL producing E.coli (21\%) was isolated from urine. As number of virulence factors increased the rate of ESBL production in E,coli decreased. A comprehensive study on the virulence factors of these bacterial strains is required. The treatment of E.coli infections is increasingly becoming difficult due to development of resistance against antibiotics. Therefore it is necessary to know the antibiotic susceptibility pattern of pathogenic E.coli to select the correct antibiotic (s) for the proper treatment of the infections.

\section{Introduction}

Escherichia coli, the most prevalent facultative gram negative bacillus in the 
human fecal flora, usually inhabit the colon as an innocuous commensal. According to the special pathogenicity theory (Orskov I. et al., 1985) special properties enabling $E$. coli to overcome host defences in a new environment are necessary in order for it to escape the limitations of the colonic mileu and move into new niches devoid of competition from other bacterial species (Eisenstein. B I. et al., 1988).

E. coli is one of the most frequent causes of extra intestinal diseases including urinary tract infections (UTI). However, E. coli, when enters into unnatural sites can cause variety of infectious diseases such as wound infections, bacteraemia, meningitis and other soft tissue infections (Picard B, Garcia JS et al., 1999). E. coli present in the gastrointestinal tract as commensals provide the pool for initiation of UTI. Urinary tract infection is one of the most important causes of morbidity and mortality. E. coli is the most frequent urinary pathogen isolated from $50 \%-90 \%$ of all uncomplicated urinary tract infections.

The ability of E.coli to cause extraintestinal infections depends largely on several virulence factors which helps in survival of E. coli under adverse conditions present in those sites.

Virulence (from the Latin word for poisonous) is defined as the ability of an organism to cause disease in a particular host. In $E$. coli, virulence results from the cumulative impact of one or several special properties, or virulence factors (VFs), which serve to distinguish potential pathogens from harmless intestinal strains. The virulence of individual strains in a given infection is determined by the presence and actual expression of the virulence genes present in them and also by the environmental conditions in the host (Johnson JR, Russo TA et al., 2002).
It has been traditionally described that certain serotypes of E.coliwere consistently associated with uropathogenicity and were designated as Uropathogenic E.coli(UPEC). These isolates express chromosomally encoded virulence markers. These markers of UPEC are expressed with different frequencies in different disease states ranging from asymptomatic bacteriuria to chronic pyelonephritis (Raksha R. et al., 2003).

In the late 1970s it was recognized for the first time that E.coli strains causing urinary tract infections typically agglutinate human erythrocytes despite the presence of Mannose (Johnson, 1991) and this was mediated mainly by fimbriae. Subsequently an array of virulence factors have been proposed as virulence markers for uropathogenic isolates of E.coli. It is now recognized that there are a subset of faecal E.colihaving the above mentioned factors which can colonise periurethral area, enter urinary tract and cause symptomatic disease. These are currently defined as UPEC (Warren JW.1997).Recent studies confirm that uropathogenic $E$. coli have several attributes that are lacking in the commensal E. coli. They carry chromosomal gene clusters on 'pathogenicity islands' (Kaper JB, Nataro JP et al., 2004 and Wullt B. 2002), encoding adhesins and other virulence factors. The most important amongst these, probably, are the adhesins that help them to adhere to uroepithelium (Sandberg T et al., 1988)and this property was recognized decades ago (Eden CS, Hanson LA et al.,1976). These include type $1, \mathrm{~S}$ and $\mathrm{P}$ fimbriae, and adhesins like $\mathrm{Dr}$ (Kaper JB, Nataro JP et al., 2004). The type 1 fimbriae are widely prevalent and are probably involved in colonization of lower urinary tract (Kaper JB, Nataro JP et al., 2004 and Wullt, 2002). Mannose-sensitive haemagglutination (MSHA) denotes 
presence of these fimbriae (Brauner A. Katouli et al., 1990, Duguid JP, Clegg S et al., 1979).

In uropathogenic $E$. coli strains, virulence factors include the ability to adhere to uroepithelial cells (Svanborg Eden C et al., 1977, Orskov I et al., 1985; Karkkainen U et al., 1991), some O and K antigens (Kaijser B. 1973; Orskov I, Orkkov F et al., 1982) and resistance to phagocytosis and to the bacterial action of normal serum (Bjorksten B, Kaijser B 1978; Siegfried L, Puzova H et al., 1992). Other factors known to contribute to the virulence of E.coli include the production of $\alpha$-hemolysin $(\mathrm{AH})$, colicins, aerobactin, cytotoxic necrotizing factor and cell surface hydrophobicity (Seigfried L, Kmeova M. et al., 1994). Adherence to uroepithelial cells is mediated by fimbrial and nonfimbrialadhesins. Among the former, P, S, M and X fimbriae have been described (Domingue GJ, et al., 1985; Labigne -Roussel A et al., 1988) and these may cause mannose resistant haemagglutination (MRHA) of human erythrocytes.

Many smooth strains of gram-negative bacteria are resistant to the bactericidal action of human and animal sera, and both epidemiological and experimental data indicate that this may be an important factor in certain infections (Durack, DT, P.B Beeson et al., 1977). In urinary tract infection, resistance to serum is related to the site of infection (Gower, P.E et al., 1972) and to the severity of symptoms (Olling S et al., 1973). Investigations into the basis of serum resistance have until recently focused upon chromosomally encoded cell surface antigens.

In Escherichia coli, resistance has been attributed to the amount of lipopolysaccharide associated with the outer membrane (Wardlaw, A.C. 1963), to the amount of O-specific side-chain material compared with core material in the lipopolysaccharide (Feingold, 1969) or to the amount and haemagglutination inhibiting activity ofacidic polysaccharide (Kantigen) associated with the cells (Glynn \& Howard, 1970). Pili or fimbriae are non flagellar filamentous bacterial surface appendages composed of hydrophobic proteins. (Brinton, C.C., JR. 1965, Duguid, J.P et al.,1957 and Houvink, A. I., et al.,1950). Piliated bacteria stick to surfaces, both inorganic latex particles and organic animal or plant tissue (Brinton, C.C., Jr 1977; Duguid, J.P.1968; Zobell, C.E. 1943). Besides bacterial binding due to this general "stickiness," (Brinton, C.C., Jr., 1965). Specific attachment to certain hosts and tissues occurs (Duguid, J.P. 1968; Gibbons, R.J.1973; Savage, D.C, 1972) and is thought to be a virulence factor for bacteria colonizing or causing infection of mucous surfaces (Gibbons, R.J.1973).

The treatment of $E$. coli infections is increasingly becoming difficult because of the multidrug resistance exhibited by the organism. ESBL producing organisms pose a major problem for clinical therapeutics. The incidence of ESBL producing strains of $E$. coli among clinical isolates has been steadily increasing over the past few years resulting in limitation of therapeutic options (Mathur P KailA et al., 2002).

The knowledge of drug resistance pattern in a geographical area and the formulation of an appropriate hospital antibiotic policy will go a long way in the control of these infections. Therefore, it is necessary to know the antibiotic susceptibility pattern of pathogenic $E$. coli to select the correct antibiotics for proper treatment of infections caused by it. 
The purpose of present study was to know the incidence of Escherichia coli in symptomatic cases of extraintestinal infection at NRI Medical College and General Hospital, Chinakakani, Guntur and to study the virulence factors of Escherichia coli such as Haemolysin, serum resistance, Mannose sensitive and mannose resistant haemagglutination, Cell surface hydrophobicity and protease production. To know the drug resistance pattern in Escherichia. coli isolated from extra intestinal infections and to evaluate screening procedures for ESBL.

\section{Materials and Methods}

\section{Study Design: Cross Sectional Study}

Setting: Department of Microbiology, NRI General Hospital, Chinakakani, Guntur district, A.P.

Participants: Hospitalised patients of all age groups from whom Escherichia coli was isolated from extraintestinal infections at NRI General Hospital, Chinakakani, Guntur.

Study Period: A total of 100 isolates of Escherichia coli from extraintestinal infections obtained during six months period from June 2011 to December 2011.

Specimens collected were pus, exudates, and clean catch midstream urine, urine from indwelling catheter, blood and CSF using standard sterile procedures. The samples were processed immediately using standard procedures. The Isolates were identified based on colony morphology on blood agar, MacConkey's agar, Gram staining and by standard biochemical test.

As a control a total of 25 stool samples from apparently healthy individuals who had come for routine health checkups were screened for E.coli and studied further for virulence markers.

The E. coli isolates were maintained by inoculating nutrient agar butts and preserved at $4^{\circ} \mathrm{C}$.

\section{Detection of Virulence Factors}

Cell Surface Hydrophobicity: The cell surface hydrophobicity of E.coli was determined by salt aggregation test (SAT) (Seigfried L et al., 1994; R Raksha et al., 2003). One loopful $(10 \mu \mathrm{L})$ of bacterial suspension made in phosphate buffer was mixed with equal volume of ammonium sulphate solution of different molarity, i.e., from $0.3125 \mathrm{M}$ through 5.0Mon a glass slide and observed for one minute while rotating. The highest dilution of ammonium sulphate solution giving visible clumping of bacteria was scored as the salt aggregation test (SAT) value. Strains showing aggregation in $0.002 \mathrm{M}$ Phosphate buffer alone $\left(\mathrm{P}^{\mathrm{H}} 5.8\right)$ were considered auto aggregative. E. coli strains that had SAT value $\leq 1.25 \mathrm{M}$ were considered Hydrophobic (Seigfried L et al., 1994; R Raksha et al., 2003.)

Haemolysin Production: The cytolytic protein toxin secreted by most hemolyticE.coli isolates is known as alpha haemolysin ( $\mathrm{R}$ Raksha et al., 2003) Plate hemolysis test was done for the detection of $\alpha$-hemolysin produced by E.coli (D.J. Farrell et al., 2003). The bacteria were inoculated onto 5\% sheep blood agar and incubated overnight at $35^{\circ} \mathrm{C}$. Hemolysin production was detected by the presence of a zone of complete lysis of the erythrocytes around the colony and clearing of the medium.

Serum Resistance: Test strains were grown over night in nutrient broth, and were diluted to $10^{4} \mathrm{cfu} / \mathrm{ml}$ in $5 \mathrm{ml}$ of fresh nutrient broth. The diluted suspensions were incubated at 
$37^{\circ} \mathrm{c}$ for $2 \mathrm{~h}$ to give a $\log$ phase culture of $10^{5} \mathrm{cfu} / \mathrm{ml}$. The cultures were centrifuged $(1500 \mathrm{~g}$ for $5 \mathrm{mts})$ and the deposit resuspended in $5 \mathrm{ml}$ of phosphate buffered saline. Equal volumes $(0.2 \mathrm{ml})$ of this suspension and PNHS were mixed before incubation in a $37^{0} \mathrm{c}$ water bath at 0,60 , $120 ; 180 \mathrm{~min}$. viable counts were made on nutrient agar, all tests were done in duplicate.

According to the method of Benge (Kallenius, G., and R. Mollby et al., 1979). Strains were termed serum sensitive if the viable count dropped to $1 \%$ of the initial value and serum resistant if $>90 \%$ of organisms survived after $180 \mathrm{~min}$. Strains that gave result between these values were of intermediate sensitivity.

Haemagglutination Test: The test strain was transferred from nutrient agar to peptone water $(\mathrm{pH} 7.0)$ and grown at $37^{\circ} \mathrm{C}$ for $24 \mathrm{hrs}$. Human ' $\mathrm{O}$ ' erythrocytes were collected in Alsever solution, washed twice with PBS and 3\% suspension was prepared in the same buffer. The test was performed by mixing one drop of carefully mixed bacterial culture with one drop of RBC suspension on glass slide. The slide was rotated for one minute at room temperature and the presence and absence of macroscopic haemagglutination was noted (Vosti Kl. et al., 1979). To test the effect of D-mannose on haemagglutination a drop of mannose solution $(25 \mathrm{mg} / \mathrm{ml}$ of PBS; $\mathrm{pH} 6.8)$ was added before addition of RBC suspension and any change in the degree of haemagglutination was observed (Hagberg L,Jodal U. et al.,1981).

Gelatinase Test:Gelatinase production was tested using gelatin agar (Collee JG. et al., 1996). The plate was inoculated with test organism and incubated at $37^{\circ} \mathrm{C}$ for $24 \mathrm{hrs}$. The plate was then flooded with mercuric chloride solution. Development of opacity on the medium and zone of clearing around colonies were considered positive for gelatinase.

\section{Test for Extended Spectrum $\beta$-lactamase Production}

Screening by standard disk diffusion method: Screening for ESBL production was Done according to criteria recommended by CLSI (Jain A et al.,2003).

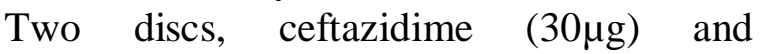
cefotaxime $(30 \mu \mathrm{g})$, were used for in vitro sensitivity testing by Kirby-Bauer disk diffusion method. Zone diameters were read using NCCLS criteria. An Inhibition Zone of $\leq 22 \mathrm{~mm}$ for ceftazidime and $\leq 27 \mathrm{~mm}$ for cefotaxime indicated. A probable ESBL producing strain requiring phenotypic confirmatory testing.

Phenotypic Confirmatory Methods: disk diffusion method was used to confirm ESBL production by E.coli strains (Bradford PA $e t$ al., 2001). Ceftazidime $(30 \mu \mathrm{g})$ vs. ceftazidime / clavulanic acid $(30 \mu \mathrm{g})$ and cefotaxime $(30 / 10 \mu \mathrm{g}) \quad$ vscefotaxime / clavulanic acid $(30 / 10 \mu \mathrm{g})$ were placed onto Mueller Hinton agar plate lawned with the test organisms and incubated overnight at $35^{\circ} \mathrm{c}$. Regardless of zone diameters, a $\geq 5$ $\mathrm{mm}$ increase in a zone diameter of an antimicrobial agent tested in combination with clavulanic acid vs. its zone size when tested alone indicated ESBL production.

Antibiotic Susceptibility Testing: The antibiotic susceptibility testing was done using modified Kirby- Bauer disk diffusion method. The antibiotic disks (Hi Media Mumbai) used were ampicillin $(10 \mu \mathrm{g})$, amikacin $(30 \mu \mathrm{g})$ co-trimoxazole (25ug), cefotaxime $(30 \mu \mathrm{g})$, ciprofloxacin $(5 \mu \mathrm{g})$ gentamicin $(30 \mu \mathrm{g})$, netlimicin $(30 \mu \mathrm{g})$. 
After $18 \mathrm{~h}$ of incubation at $37^{\circ} \mathrm{c}$, the diameter of the zone of inhibition was measured using millimeter scale around each antimicrobial disk on the undersurface of the plate. The zone size around each antimicrobial disk was interpreted as sensitive, intermediate or resistant according to CLSI criteria (Duguid, J.P., and R.R. Gillies et al., 1957).

\section{Results and Discussion}

Virulence factors enable E.coli to colonise selectively the mucosal uroepithelium, evoke an inflammatory reaction and eventually proceed from lower urinary tract to renal cavities and tissue invasion. The capacity of E.coli to produce many virulence factors contributes to its pathogenicity. E.coli is able to cause a variety of infections, like urinary tract infections (UTI), cholecystitis, wound infections, bacteraemia, neonatal meningitis, pulmonary infections and many more. These virulence factors enable some members of the normal flora to elicit an infection by overcoming the host defence mechanisms (Emody L et al., 2003).

A total number of samples with extra intestinal infections received at the Department of Microbiology, NRI General Hospital Chinakakani during the period June 2011 to December 2011 were 2,600. Among these, pathogens were isolated from 950 (36.5\%) samples. Klebsiella was predominant isolate $360(37.8 \%)$ followed by Pseudomonas 250 (26.3\%), E.coli 200 (21\%), Streptococcus spp.110 (11.57\%) and Proteus 40 (4.2\%).

A total of 100 E.coli isolates were selected from these cases with extra intestinal infection attending Out patient department and In patients of Medical, Gynecology\& Urology departments, NRI General Hospital, Chinakakani during the period June 2011 to December 2011.These 100 isolates of E.coli were investigated for various virulence factors. Faecal isolates of E.coli from 25 adult healthy individuals were included as controls. The Chi -square test was used to find the significance of the study parameters.

Table 1 shows outpatient and Inpatient distribution. There were 44 female and 27 male patients attended outpatient department. Only 18 female \& 11 male patients were admitted in the hospital. Majority of the female patients with UTI were treated on out patient basis.

Table. 2 shows specimen wise distribution of isolates. Out of 100 isolates of E.coli 5 (5\%) were from pus, 92 (92\%) from urine, 1 from blood, 1 from ascitic fluid \&1 from sputum.

Table.3 shows Virulence factors such as hemolysin, surface hydrophobicity, serum resistance, mannose resistant haemagglutination, and protease were studied for all the isolates.

The most common virulence factor identified was Serum resistance in 51(51\%) isolates. Haemolysin was produced by 47(47\%) isolates, 23 strains were hydrophobic. In the present study 20 isolates were MRHA and only two isolates produced Protease.

Table.4. In the study group hemolysin production was observed in $47 \%$ of E.coli isolates, where as in controls only $4(16 \%)$ isolates exhibited hemolysin production. The difference is significant.

Haemolysin production is associated with pathogencity of E.coli especially the more severe forms of infection (Johnson JR.1991). Haemolysin is probably produced in vivo during UTI by uropathogenic strains. It is likely that the provirulence activity of 
haemolysin is multifactorial including release of iron from erythrocytes disruption of phagocyte function and direct toxicity to host tissue.

The cytolytic protein toxin secreted by most hemolytic E.coli strains is $\alpha$ haemolysin. E.coli also produces cell associated lysine on blood agar plates and haemolysin was not further characterized. It can be considered as cytotoxic nectotising factor (hemolysin). In our study hemolysin production was more common among the isolates of urine. The number of faecal isolates showing haemolysin is considerably less than that of uro isolates The difference between cases and controls for production of haemolysin was significant $(\mathrm{p}<0.01)$. R.Raksha et al.,2003 and Blanco J.1990 have quoted higher incidence of $41 \%$. Johnson JR.et.al.,1991, reported 38\%of urinary and $12 \%$ of faecal isolates which is comparable to our study. Whereas Mandal P.et al.,2001, reported haemolysin positive in $16.6 \%$, S.Sharma et al., 2007 reported hemolysin positive (23.7\%) among the isolates from blood.

Table. 5 shows Cell surface hydrophobicity, in the study group it was observed in $23 \%$ of E. coli isolates, where as in controls only 3 $(12 \%)$ isolates exhibited cell surface hydrophobicity.

Surface hydrophobicity is another important virulence factor of E.coli that causes extraintestinal infections. The role of surface hydrophobicity in mediating bacterial adherence to mammalian cells was conceived by Mudd S \&Mudd EBH. 1924.Crystalline surface layer S' layer present on both gram negative and gram positive organisms play a role in this Hydrophobicity is a recently described normal virulence mechanism by E.coli (Sleytr B, Messner P.1983).
In the present study $23 \%$ of the strains were hydrophobic and the difference between cases and controls is highly significant $(\mathrm{p}<0.01)$

The high hydrophobicity of the bacterial cell surface promotes their adherence to various surfaces like mucosal epithelial cell. S. Sharma et al., 2007, reported $33.4 \%$ whereas R. Raksha et al., 2003, quoted higher incidence of $26.36 \%$

Table.6 In the present study 51\% of the isolates were resistant to serum bactericidal activity and $24 \%$ were serum resistant among control strains. The difference is statistically significant $(\mathrm{p}=0.01)$. Majority of which were isolated from pus $(60 \%)$ and urine $(50 \%)$.

Serum resistance is the property by which the bacteria resist killing by normal human serum due to lytic action of alternative complement system (Johnson, 1991). Bacterial resistance to killing by serum results from individual or combined effect of capsular polysaccharide $\mathrm{O}$ polysaccharide and surface proteins (Montenegro MA, et al., 1985).

S. Sharma et al., 2007, reported serum resistance in $(86.7 \%)$ of E.coli isolated from urine and blood $77.4 \%$. Raksha et al., 2003, reported $32.7 \%$ of E.coli isolates were serum resistant. Seigfried L. et al., 1994, reported serum resistance in $68 \%$ isolates while Srikanth N S, et al., 2003, noted serum resistance only in $4.86 \%$ of isolates.

Isolates from patients with pyelonephritis, cystitis and bacteraemia are typically serum resistant whereas patients with asymptomatic bacteriuria have serum sensitive strains (Johnson JR. 1991). The serum resistant gram negative bacteria possess a significant survival advantage in 
the blood during bacteraemia. There is a strong correlation between serum resistance and the ability of a variety of gram negative bacteria to invade and survive in human blood stream.

A previous study has shown that serum resistance is important in the pathogenesis of symptomatic UTI regardless of the severity.

Table.7. In study group, Mannose resistant haemagglutination was observed in $20 \%$ E.coli isolates, $7 \%$ were mannose sensitive. There was no haemagglutination in $73 \%$ isolates.

In controls $4(16 \%)$ isolates were MRHA positive, $4(16 \%)$ were MSHA positive. There was no haemagglutination in 17 $(68 \%)$ isolates. Highly significant difference was observed in the haemagglutination property of cases and controls $(\mathrm{P}<0.001)$.

Haemagglutination is mediated by fimbriae (Duguid JP. et al., 1979). MRHA can be mediated by $\mathrm{P}$ fimbriae and also X, FIC, Dr fimbiae. Thus MRHA positive strains can be considered as UPEC most likely having $\mathrm{P}$ fimbiae.

Table. 8 shows that a total of $13 \%$ of isolates exhibited all the four virulence factors, i.e. Haemolysin, Serum resistance, Cell surface hydrophobicity, and MRHA or MSHA. 14\% E.coli strains did not show the presence of any virulence factors.

Table. 9 shows that among controls none of the isolates exhibited all the four virulence factors. $6(24 \%)$ isolates exhibited 2 different virulence factors. $13(52 \%)$ E.coli isolates did not reveal presence of any of these virulence factors.

\section{Varied Range of HA}

Yasmeen Kausar et al., 2009, observed
MRHA in 30\% MSHA 36\%. Raksha et al., 2003, observed MRHA in 30\%, MSHA $36 \%$. Raksha.et al., 2003, reported $30.9 \%$ of cases and $12 \%$ of controls were MRHA positive. Johnson JR. et al., 1991, observed $58 \%$ of urinary isolates and $19 \%$ of faecal isolates were MRHA positive.

Seigfried et al., 1994, observed MRHA in $43.45 \%$, MSHA in $13.6 \%$. Blanco J. et al., 1990, reported 48\% MRHA. As per Hagberg $\mathrm{L}$ et al., 1981, the MRHA of human erythrocyte was observed in $77 \%$ of acute pyelonephritis strains, $35 \%$ of acute cystitis strains, $18 \%$ of asymptomatic bacteriuria strains and $16 \%$ of normal faecal isolates. The high proportion of strains with MSHA were found among acute cystitis strains $91 \%$.

Study at St. Johns Medical College, Bangalore reported MRHA in $34.7 \%$ to $30.9 \%$ and where as Mandal $\mathrm{P}$ et al., 2001, reported MRHA $16.6 \%$ and MSHA in $20 \%$.

\section{Correlation between Virulence Factors}

The present study also revealed expression of multiple virulence factors by extra intestinal E-coli. Most of the haemolysin producing isolates were also hydrophobic, serum resistant and MRHA positive.

In our study $13 \%$ of isolates showed the presence of all the four virulence factors. Presence of three virulence factors was noted in $5 \%$ of isolates and presence of two virulence factors was noted $4 \%$ of isolates. This is consistent with the findings of previous study. A previous study indicated that although virulence of an organism cannot be accurately predicted on the basis of its measurable virulence factor phenotype, the presence of multiple virulence factors does increase the virulence of organisms. The strains with more extensive complement of virulence factors 
are more effective pathogens, and the compromising host conditions decrease in the need for multiple virulence factors in strains causing serious infections.

Haemolysin and serum resistance was seen in $15 \%$ of isolates. Serum resistance and cell surface hydrophobicity in $12 \%$, serum resistance \& MRHA in 5\%. Hemolysin and cell surface hydrophobicity in $7 \%$. Only single factor that is haemolysin production was observed in $10 \%$. Serum resistance in $5 \%$, cell surface hydrophobicity in $7 \%$, MRHA in $3 \%$ and MSHA in $1 \%$. $14 \%$ of isolates did not show the presence of any virulence factors. Sharma S et al.,2007, showed the combination of all three virulence factors such as hemolysin, surface hydrophobicity, and serum resistance was present in $11.2 \%$ of isolates.

This is the consistent with the findings of our study. Among the controls none of the isolates exhibited all the virulence factors. Yasmeen kausar.2009, reported the presence of all the three virulence factors, that is haemolysin, serum resistance, and haemagglutinating activity in $0.5 \%$ of E.coli isolates. The practical goal of any pathogen is the development of specific antivirulence factor interventions to prevent infection. The practical application of understanding of $E$. coli virulence factors to the prevention and treatment of UTI has only just begun (Johnson JR. 1991).

Table.10 shows that majority $91 \%$ of E.coli isolates were sensitive to Amikacin. 40 to $64 \%$ were sensitive to Co-trimoxazole, Cefotaxime and Netilimicin. 30 to $36 \%$ isolates were sensitive to Ciprofloxacin and Cefotaxime. 70 to $99 \%$ was resistant to Ciprofloxacin and Ampicillin. Antibiotic susceptibility pattern was studied for all isolates of E.coli.

Resistance was observed to commonly used antibiotics such as ampicillin, ciprofloxcin, cefotaxime, co-trimoxazole and ceftazidime. The greater prevalence of resistance to common antibiotics has also been reported by other workers (Chitnis SV. et al., 2003; Wiener J. 1999).

The presence of multidrug resistance may be related to the dissemination of antibiotic resistance among hospital isolate of E.coli. Maximum number of isolates $99 \%$ was resistant to ampicillin, and the lowest 36\% and $9 \%$ to nitillin and amikacin. These results are consistent with the previous studies on drug resistance in E.coli (Gupta K et al., 1999 and David A. et al., 2004).

We observed a low rate of ESBL production by E.coli.Sharma S.et al., 2007, reported a high rate of ESBL production by E.coli which may be due to the selective pressure imposed by extensive use of antimicrobials. The indiscriminate use of cephalosporins is responsible for the high rate of selection of ESBL producing microorganisms. For predicting ESBL production, it is important to mention that for screening test, negative results are a better guide than positive results. Therefore confirmation of all positive results by screening should be done to prevent unnecessary avoidance of conventional $\beta$-lactams.

Table.11 shows the analysis of drug resistance pattern among 100 isolates of E.coli. maximum number (99\%) were resistant to ampicillin and lowest to amikacin (9\%). ESBL production was detected in $32 \%$ of isolates; the maximum number of ESBL producing E.coli $25 \%$ was isolated from urine.

Out of 64 isolates, resistant to cefotaxime $20 \%$ were ESBL producers. On the other hand, of the 75 isolates which were positive for ESBL by screening test, 32 were positive 
by confirmation test. All the ESBL producing isolates were studied for presence of multiple virulence factors.

Application of Gaussians formulae showed that there was significant association between multiple virulence factors and ESBL production in extra intestinal E.coli. As a number of virulence factors increased, the rate of ESBL production in E.coli decreased.

Table.1 Outpatient and Inpatients Distribution

\begin{tabular}{|ccc|}
\hline Department & Males & Females \\
OP & 27 & 44 \\
IP & 11 & 18 \\
TOTAL & 38 & 62 \\
\hline
\end{tabular}

Table.2 Specimen Wise Distribution of Isolates

\begin{tabular}{|cc|}
\hline Nature of specimen & Number \\
Pus & 5 \\
Urine & 92 \\
Blood & 1 \\
Ascitic fluid & 1 \\
Sputum & 1 \\
Total & 100 \\
\hline
\end{tabular}

Table.3 Specimen Wise Distribution of Virulence Factors in Extraintestinal E.coli

\begin{tabular}{|l|c|c|c|c|c|}
\hline & $\begin{array}{c}\text { Hemolysin } \\
\text { production }\end{array}$ & Hydrophobicity & $\begin{array}{c}\text { Serum } \\
\text { resistance }\end{array}$ & MRHA & Protease \\
\hline Pus & $\begin{array}{c}4 \\
(80 \%)\end{array}$ & 0 & $\begin{array}{c}3 \\
(60 \%)\end{array}$ & 3 & 0 \\
\hline Urine & 40 & 21 & 46 & $17(18.4 \%)$ & 2 \\
$(43.4 \%)$ & $(22.8 \%)$ & 0 & 0 & 0 \\
\hline Blood & 1 & 1 & 1 & 0 & 0 \\
\hline Ascitic fluid & 1 & 1 & 1 & 0 & 0 \\
\hline Sputum & 1 & 23 & 51 & 20 & 2 \\
\hline Total & 47 & 0 & $0 \%)$ & 0 \\
\hline
\end{tabular}

Table.4 Haemolysin Production

\begin{tabular}{|cccc|}
\hline $\begin{array}{c}\text { Hemolysin } \\
\text { Production }\end{array}$ & $\begin{array}{c}\text { Study group } \\
(\mathbf{n}=\mathbf{1 0 0})\end{array}$ & $\begin{array}{c}\text { Control } \\
(\mathbf{n}=\mathbf{2 5})\end{array}$ & P value \\
Positive & 47 & $4(16 \%)$ & $\mathrm{P}<0.01$ \\
Negative & 53 & $21(84 \%)$ & \\
\hline
\end{tabular}


Table.5 Cell Surface Hydrophobicity

\begin{tabular}{|cccc|}
\hline $\begin{array}{c}\text { Cell surface } \\
\text { hydrophobicity }\end{array}$ & $\begin{array}{c}\text { Cases } \\
\mathbf{n = 1 0 0}\end{array}$ & $\begin{array}{c}\text { Control } \\
\mathbf{n = 2 5}\end{array}$ & $\mathbf{P}$ value \\
Positive & 23 & $3(12 \%)$ & $\mathrm{p}<0.01$ \\
Negative & 77 & 22 & \\
\hline
\end{tabular}

Table.6 Serum Resistance

\begin{tabular}{|cccc|}
\hline Virulence & Cases & Controls & P Value \\
Serum resistance & 51 & $6(24 \%)$ & $\mathrm{P}=0.01$ \\
Serum sensitive & 49 & $19(76 \%)$ & \\
\hline
\end{tabular}

Table.7 Haemagglutination Activity

\begin{tabular}{|c|c|c|c|}
\hline $\begin{array}{c}\text { Haemagglutination } \\
\text { activity }\end{array}$ & $\begin{array}{c}\text { Cases } \\
(\mathbf{n = 1 0 0 )}\end{array}$ & $\begin{array}{c}\text { Controls } \\
(\mathbf{n}=\mathbf{2 5})\end{array}$ & P value \\
\hline MRHA & 20 & $4(16 \%)$ & \\
\hline MSHA & 7 & $4(16 \%)$ & $\mathbf{P}=\mathbf{0 . 0 0 1}$ \\
\hline NO HA & $\mathbf{7 3}$ & $\mathbf{1 7}(\mathbf{6 8 \%})$ & \\
\hline
\end{tabular}

Table.8 Correlation of Different Virulence Factors in Clinical Isolates

\begin{tabular}{|ccccccc|}
\hline S.NO & Haemolysin & SR & CSH & MRHA & MSHA & Total \\
1 & + & - & - & - & - & 10 \\
2 & + & - & - & + & - & 2 \\
3 & - & + & - & - & - & 5 \\
4 & - & + & - & + & - & 5 \\
5 & - & - & + & - & - & 7 \\
6 & - & - & - & + & - & 3 \\
7 & - & - & - & - & + & 1 \\
8 & + & - & + & - & - & 7 \\
9 & - & + & + & - & - & 12 \\
10 & + & + & & - & - & 15 \\
11 & + & + & - & - & + & 5 \\
12 & + & + & + & + & - & 13 \\
13 & - & - & - & - & - & 14 \\
\hline
\end{tabular}


Table.9 Correlation of Different Virulence Factors in Controls

\begin{tabular}{|ccccccc|}
\hline S.NO & Hemolysin & SR & CSH & MRHA & MSHA & Percentage \\
1 & + & - & - & - & - & $2(8 \%)$ \\
2 & + & - & + & + & - & $2(8 \%)$ \\
3 & - & + & - & - & - & $1(4 \%)$ \\
4 & - & + & + & + & - & $2(8 \%)$ \\
5 & - & - & - & - & - & $2(8 \%)$ \\
6 & - & - & + & + & - & $1(4 \%)$ \\
7 & - & - & - & - & + & 0 \\
8 & + & - & - & - & - & 0 \\
9 & - & + & - & - & - & $2(8 \%)$ \\
10 & + & + & - & - & - & 0 \\
11 & + & + & - & - & + & 0 \\
12 & + & + & + & + & - & 0 \\
13 & - & - & - & - & - & $13(52 \%)$ \\
\hline
\end{tabular}

Table.10 Antibiotic Susceptibility Pattern

\begin{tabular}{|ccc|}
\hline Antibiotics & Sensitive & Resistant \\
Ampicillin & 1 & 99 \\
Amikacin & 91 & 9 \\
Co-trimoxazole & 40 & 6 \\
Cefotaxime & 36 & 64 \\
Ciprofloxacin & 30 & 70 \\
Netilimicin & 64 & 36 \\
Ceftazidime & 43 & 57 \\
\hline
\end{tabular}

Table.11 Presence of Multiple Virulence Factors in ESBL Producing Isolates of E.coli

\begin{tabular}{|c|c|c|}
\hline $\begin{array}{c}\text { Multiple } \\
\text { virulence } \\
\text { factor }\end{array}$ & ESBL +VE & ESBL $-\mathbf{V E}$ \\
\hline+ & 23 & 52 \\
\hline- & 9 & 16 \\
\hline Total & 32 & 68 \\
\hline
\end{tabular}


Figure.1 Out Patient and Inpatients Distribution

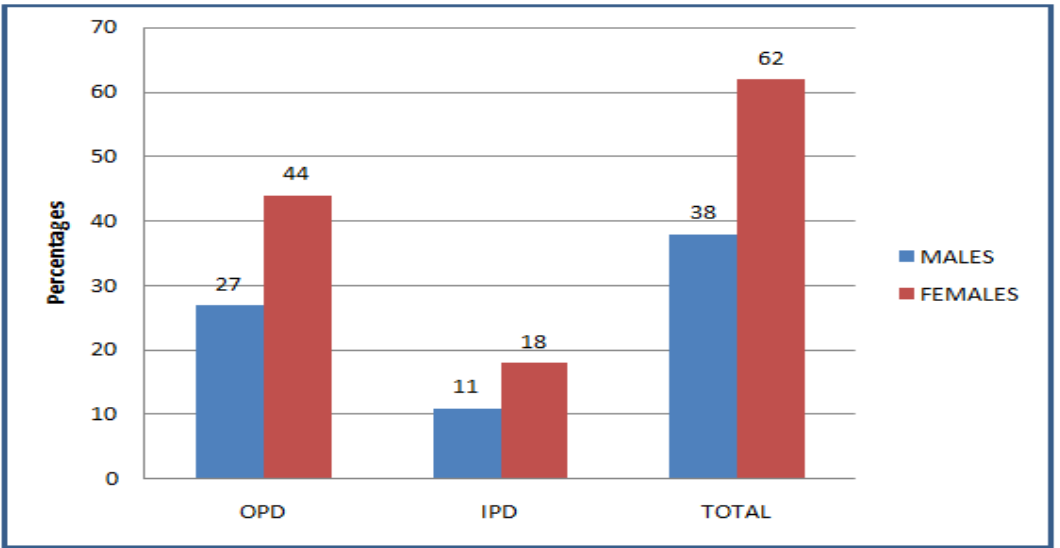

Figure.2 Specimen wise distribution of isolates

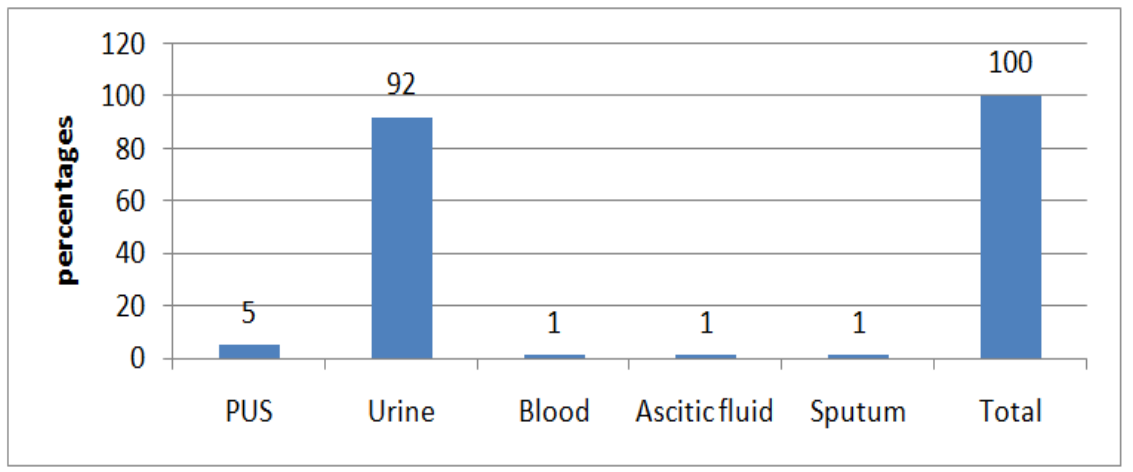

Figure.3 Specimen wise distribution of virulence factors in extra intestinal E.coli

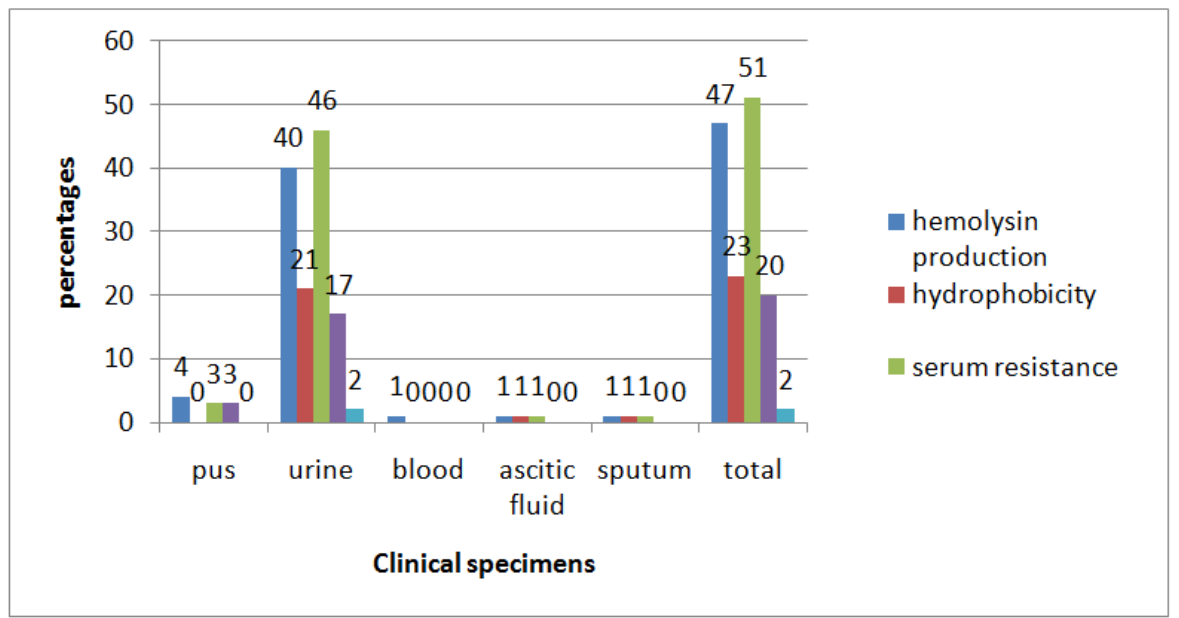


Figure.4 Haemolysin production

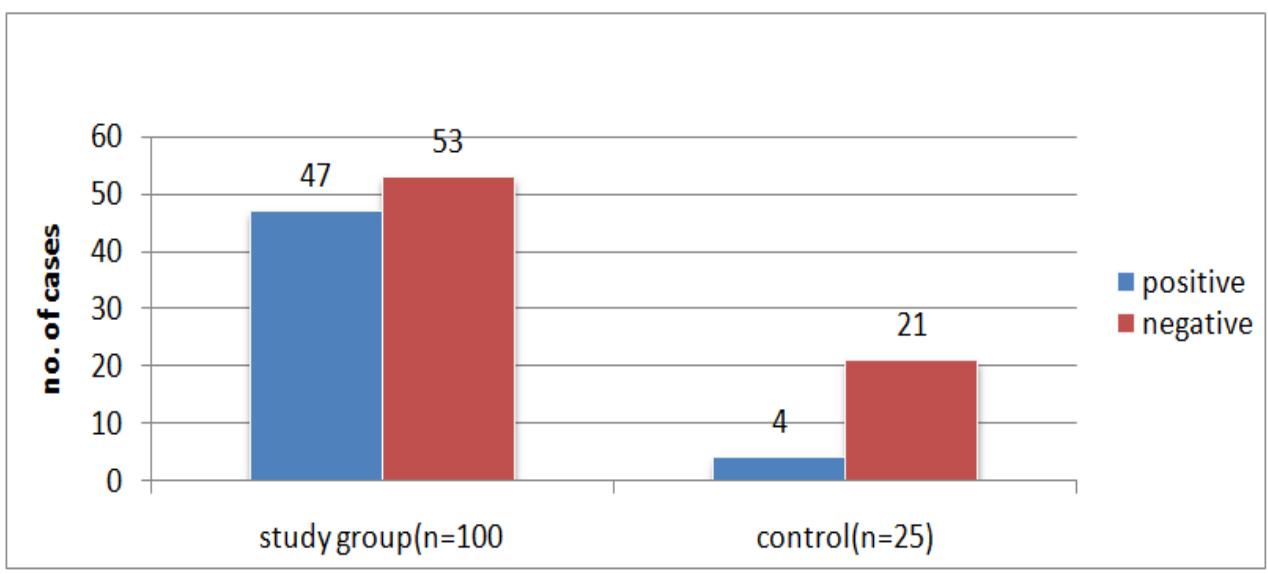

Figure.5 Cell surface hydrophobicity

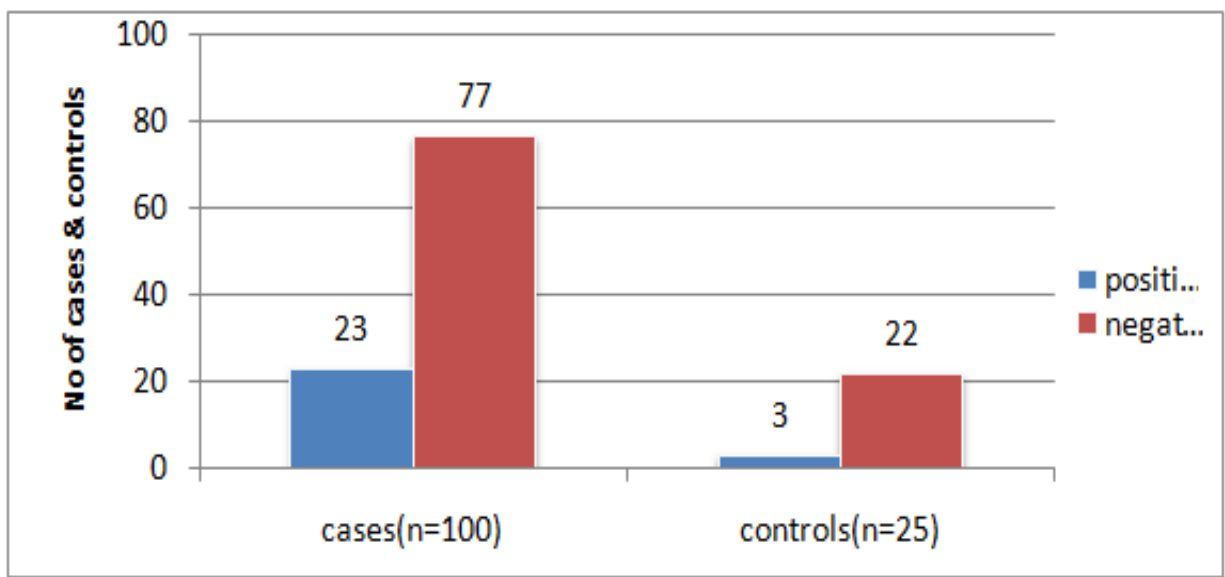

Figure.6 Serum Resistance

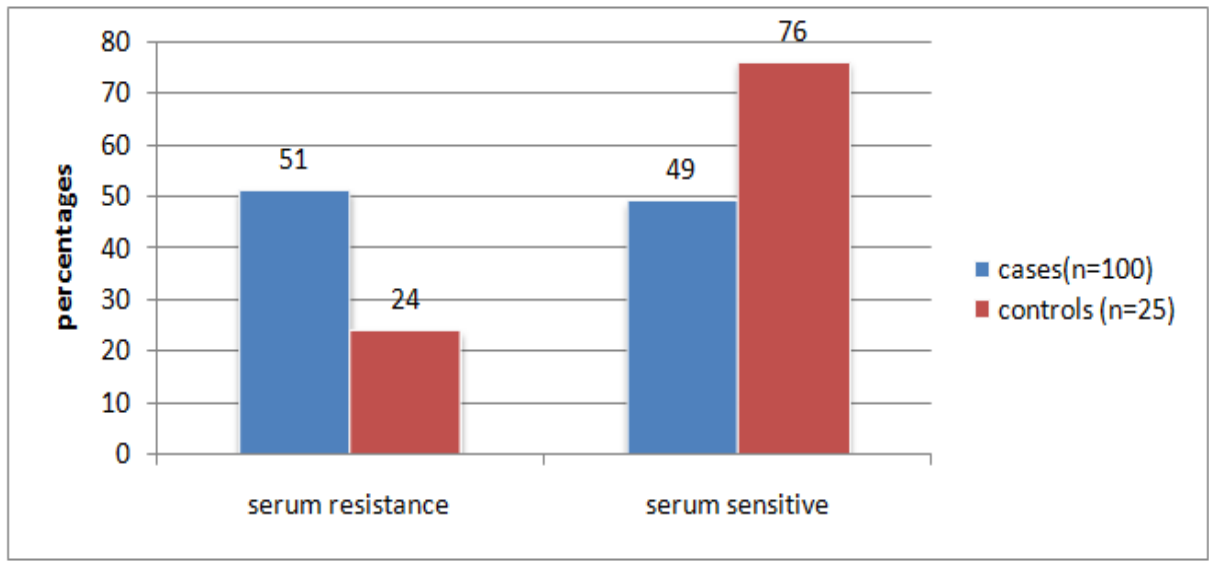


Figure.7 Haemagglutination activity

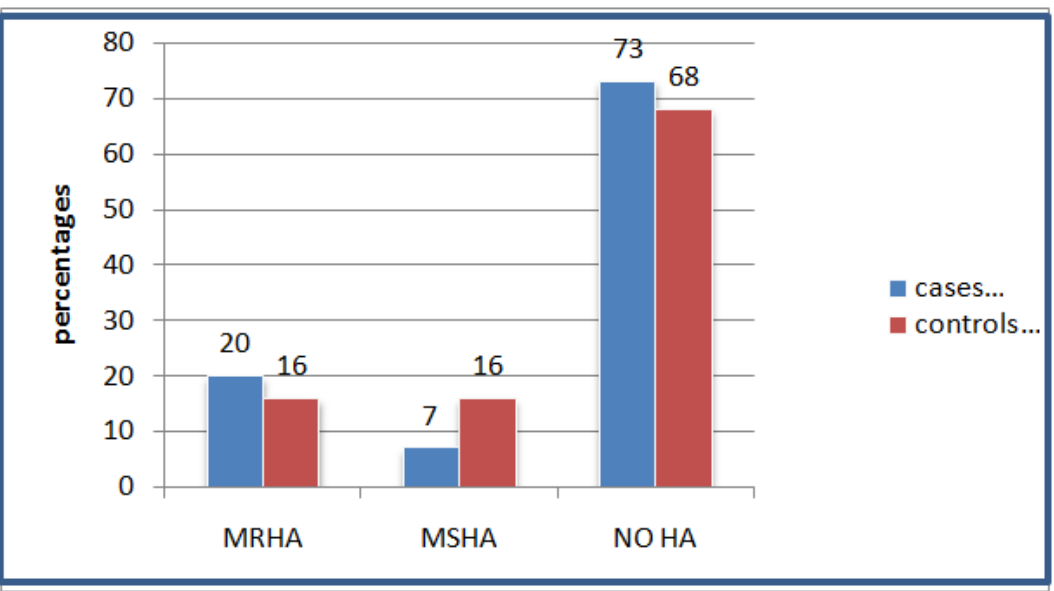

Figure.8 Antibiotic Susceptibility Pattern

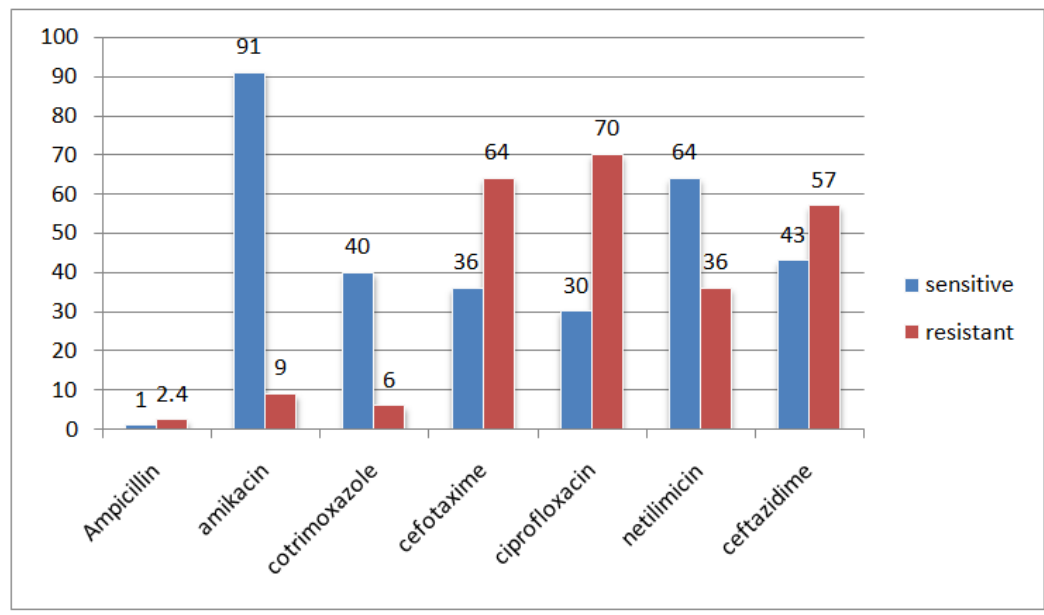

In the present study, we found that a majority $(76.47 \%)$ of ESBL negative strains of E.coli produced multiple virulence factors. Whereas $(28.12 \%)$ of the ESBL producers did not produce multiple virulence factors. Sharma S. et al., 2007, found that a majority $(68 \%)$ of $\mathrm{ESBL}$ negative stains of E.coli produced multiple virulence factors, whereas most of the ESBL producers $(68.2 \%)$ did not produce multiple virulence factors.

These results support the hypothesis that although virulence factors and antibiotic resistance may confer increased fitness for extra intestinal infections in humans. They may do so via mutually exclusive pathways and in indistinct populations (Johnson JR et $a l ., 2003)$.A rise in the number of virulence factors was associated with a decrease in the rate of ESBL production. A robust virulence factor repertoire may be essential for a pathogen to overcome intact host defences. Whereas it may be unnecessary in a compromised host, where antibiotic resistance may provide a substantial advantage to the survival of pathogens.

In conclusion, Majority of the isolates of E.coli were from urine 92\%. Among 100 
E.coli isolated from various extraintestinal infections $51 \%$ of isolates exhibited serum resistance. Hemolysin was produced by $47 \% .23 \%$ of strains were hydrophobic and MRHA positive 20\%.Compared to control group i.e faecal E.coli isolates the difference was highly significant for cell surface hydrophobicity and Haemagglutination activity. E. coli causing UTI in different patient populations differ in their pathogenic potential and susceptibility to antimicrobials. The present study has shown the capacity of $E$. coli to adapt and survive in different tissues by producing virulent factors and developing drug resistance. The expression of virulence factor(s) may depend on the need and it varies in different kinds of infections. Drug resistance is on the rise among $E$. coli strains that cause human infections. Proper selection of antibiotics for treatment depends on the results of antibiotic sensitivity test. Therefore, the correct detection of drug resistant bacteria is important. Judicious use of antibiotics and good antibiotic policy are needed to limit the emergence and spread of antibiotic resistance in bacteria.

\section{Acknowledgement}

We are extremely grateful to Dr. K. Sree Rama Rao and Dr M. Ramesh Babu,HOD \& Professor for their invaluable guidance, suggestions and support. We express our sincere thanks to Mrs.Saritha (Biostatistician, department of community medicine) and each and every staff of Department of Microbiology, NRI Medical College for their help and co-operation.

\section{References}

Brauner, A., Katouli, M., Tullus, K., Jacobson, S.H. 1990. Cell surface hydrophobicity, adherence to HeLa cell cultures and haemagglutination pattern of pyelonephritogenic Escherichia coli strains. Epidemiol. Infect., 105: 255-63.

Bradford, P.A. 2001. Extended spectrum $\beta$ lactamases $21 \quad$ century Characterisation, epidemiology and detection of this important resistance threat. Clin. Microbiol., 933-51.

Brinton, C.C., Jr. 1965. The structure, function, synthesis and genetic control of bacterial pili and a molecular model for DNA and RNA transport in gram negativebacteria. Trans. N. Y. Acad. Sci., 27: 1003-1054.

Bjorksten, B., Kaijser, B. 1978. Interaction of human serum and neutrophils with Escherichia coli strains differences between strains isolated from urine of patients with pyelonephritis or asymptomatic bacteriuria. Infect. Immun., 122: 308-311.

Blanco, J., Alonso, M.P., Gonzalez, E.A., Blanco, M., Garabal, J.I. 1990. Virulence factors of bacteraemic Escherichia coli with particular reference to production of cytotoxic necrotoxic necrotizing factor $(\mathrm{CNF})$ by P-fimbriate strains. J. Med. Microbiol., 31: 175-183.

Clinical and Laboratory Standards Institute. 2006. Performance standards for antimicrobial disk tests; Approved standards, $9^{\text {th }}$ ed, CLSI Document M2 - A9 ,VOL. 26 NO 1, Wayne PA.

Collee, J.G., Miles, R.S.,Watt, B. 1996. Tests for identification of bacteria In: Mackie and McCartney Practical Medical Microbiology $14^{\text {th }}$ edColleeJG.Fraser AG. Marnion BP.Sunmon A editors (Churchill Livingston: New York). p.131-49.

Chitnis, S.V., Chitris, V., Sharma, N., Chitnis, D.S. 2003. Current status of drug resistance among gram negative bachilli isolated from admitted cases in a tertiary care centre. J. Assoc. 
Physicians India, 51: 28-31.

Domingue, G.J., Roberts, J.A., Laucirica, R., et al. 1985. Pathogenic significance of P-fimbriatedEscherichia coli in urinary tract infections. J. Urol., 133: 983-987.

Duguid, J.P. 1968. The function of bacterial fimbriae. Arch. Immunol. Ther. Exp., 16: $173-188$.

Duguid, J.P., Gilies, R.R. 1957. Fimbriae and adhesive properties in dysentery bacilli. J. Pathol. Bacteriol., 74: 397411.

David, A., Talan, Kurt, G., Naber, Juan Palou, David Elkharrt. 2004. Extended release ciprofloxacin (Cipro XR) for treatment of urinary tract infections. Int. J. Antimicrob. Agents, 2381: 5466.

Farrell, D.J., Morrissey, I., De rubies, D., Robbins, M., Felmingham, D. 2003. A UK multicentre study of the Antimicrobial susceptibility of Bacterial pathogens causing urinary tract infection. J. Infect., 46(2): 94100.

Duguid, J.P., Clegg, S., Wilson, M.I. 1979. The fimbrial and nonfimbrialhaemagglutinins of Escherichia coli. J. Med. Microbiol., 12: 213-227.

Duguid, J.P., Gillies, R.R. 1957. Fimbriae and adhesive properties in dysentery bacilli. J. Pathol. Bacteriol., 74: 3973412.

Durack, D.T., Beeson, P.B. 1977. Protective role of complement in experimental Escherichia coli endocarditis. Infect. Immun., 16: 213-217.

Eden, C.S., Hanson, L.A., Jodal, U., Lindberg, U., Akerlund, A.S. 1976. Variable adherence to normal human urinary tract epithelial cells of Escherichia coli strains associated with various forms of urinary tract infection. Lancet, 1: 490-2.
Eisenstein, B.I., Jones, G.W. 1988. The Spectrum of infections and pathogenic mechanisms of Escherichia coli. Adv. Intern. Med., 33: 231-252.

Emody, L., Leremuo, M., Nagy, G. 2003. Virulence factor of uropathogenic Escherichia coli. Int. J. Antimicrob. Agents, 22: 29-33.

Feingold, D.S. 1969. The serum bactericidal reaction. IV. Phenotypic conversion of Escherichia coli from serum resistance to serum sensitivity by diphenylamine. J. Infect. Dis., 120: 437-444.

Glynn, A.A., Howard, C.J. 1970. The sensitivity of complement strains of Escherichia coli related to their $\mathrm{K}$ antigens, Immunol., 18: 331-346.

Gower, P.E., Taylor, P.W., Koutsaimanis, K.G., Roberts, A.P. 1972. Serum bactericidal activity in patients with upper and lower urinary tract infections. Clin. Sci., 43: 13-22.

Gibbons, R.J. 1973. Bacterial adherence in infection and immunity. Rev. Microbiol., (Sao Paulo) 4: 49-60.

Gupta, K., Scholes, D., Stamm, W.E. 1999. Increasing prevalence of antimicrobial resistance among uropathogens causing acute uncomplicated cystitis in women. JAMA, 281: 736-8.

Hagberg, L., Jodal, U., Lidin Janson, G., Lindberg, V., Swanberg Eden, G. 1981. Adhesion haemagglutinatio and virulence of E.coli causing urinary tract infections. Infect. Immun., 31: 564-570.

Houvink, A.L., van Iterson, W. 1950. Electron microscopical observations on bacterial cytology. II. A study on flagellation. Biochim. Biophys. Acta., 5: $10-44$.

Johnson, J.R., Russo, T.A. 2002. Extraintestinal pathogenic Escherichia coli: "the other bad E coli". J. Lab. Clin. Med., 139: 155-162. 
Jain, A., Roy, I., Gupta, M.K., Kumar, M., Agarwal, S.K. 2003. Prevalence of extended spectrum $\beta$-Lactamase producing gram negative bacteria in septicaemic neonates in a tertiary care hospital. J. Med. Microbiol., 52: 4215.

Johnson, J.R. 1991. Virulence factors in Escherichia coli Urinary tract infection. Clin. Microbiol. Rev., 4: 80128.

Johnson, J.R., Kushowski, M.A., Owens, K., Gajewski, A., Winokur, P.L. 2003. Phylogenetic origin and virulence genotype in relation to resistance to fluoroquinolones and extended spectrum cephalosporins and cephamycins among Escherichia coli isolates from animals and humans. $J$. Infect. Dis., 188: 759-68.

Johnson, J.R., Moseley, S.L., Roberts, P.L., Stamm, W.E. 1988. Aerobactin and other virulence factor genes among strains of Escherichiacoli causing urosepsis: association with patient characteristics. Infect. Immun., 56: 405-412.

Kaper, J.B., Nataro, J.P., Mobley, H.L. 2004. Pathogenic Escherichia coli. Nat. Rev. Microbiol., 2: 123-40.

Kallenius, G., Mollby, R. 1979. Adhesion of Escherichia coli to human periurethral cells correlated to mannose-resistant agglutination of human erythrocytes. FEMS Microbiol. Lett., 5: 295-299.

Hagberg, L., Jodal, U., Lidin Janson, G., Lindberg, V., Swanberg Eden, G. 1981. Adhesion, Hemagglutination and virulence of Escherichia coli causing urinary tract infections. Infect. Immun., 31: 564-570.

Labigne-Roussel, A., Falkow S. 1988. Distribution and degree of heterogeneity of the afimbrialadhesion-encoding operon (afa) among uropathogenic Escherichia coli isolates. Infect. Immun., 56: 640-648.

Mandal, P., Kapil, A., Goswami, K., Das, B., Dwivedi, S.N. 2001. Uropathogenic Escherichia coli causing urinary tract infection. Indian J. Med. Res., 114: 207-211.

Montenegro, M.A., Bittersuermann, D., Jimmis, J.K. et al. 1985. Serum resistance and pathogenicity related factors in clinical isolates of Escherichia coli and other gram negative bacteria. J. Gen. Microbiol., 131: 1511-21.

Mudd, S., Mudd, E.B.H. 1924. The penetration of bacteria through capillary spaces IV.A Kinetic mechanism in interfaces. J. Exp. Med., 40: 633-45.

Mathur, P., Kail, A., Das, B., Dhawan, B. 2002. Prevalence of ESBL producing gram negative bacteria in a tertiary care hospital. Indian J. Med. Res., 115: 153-7.

Olling, S., Hanson, L.A., Holmgren, J., Jodal, U., Lincoln, K., Lindberg, U. 1973. The bactericidal effect of normal human serum on E.coli strains from normals and from patients with urinary tract infections. Infection, 1: 24-28.

Orskov, I., Orskov, F. 1985. Escherichia coli in extraintestinal infections. $J$. Hyg., 95: 551-575.

Picard, B., Garcia, J.S., Gouriou, S., Duriez, P., Brahim, N., Bingen, E., et al. 1999. The link between phylogeny and virulence in Escherichia coli extraintestinal infection. Infect. Immune., 67: 546-53.

Raksha, R., Srinivasa, H., Macaden, R.S. 2003. Occurrence and characterization of uropathogenic Escherichia coli in urinary tract infections. Indian $\mathrm{J}$. Med. Microbiol., 21(2): 102-107.

Sharma, S., Bhat, G.K., Shenoy, S. 2007. Virulence factors and drug resistance in Escherichia coli isolated from 
extraintestinal infections. Indian $J$. Med. Microbiol., 25(4): 369-73.

Seigfried, L., Kmetova, M., Hana Puzova, Maria Molokacova, Filka, J. 1994. Virulence associated factors in Escherichia coli strains isolated from children with urinary tract infections. J. Med. Microbiol., 41: 127-152.

Sleytr, B., Messner, P. 1983. Crystalline surface layers of bacteria. Ann. Rev. Microbiol., 37: 311-339.

Sandberg, T., Kaijser, B., Lidin-Janson, G., Lincoln, K., Orskov, F., Orskov, I., et al. 1988. Virulence of Escherichia coli in relation to host factors in women with symptomatic urinary tract infection. J. Clin. Microbiol., 26: $1471-6$.

Srikant, N.S., Macaden, R. 2003. Uropathogenic Escherichia coli - a preliminary study. Indian J. Med. Microbiol., 46(1): 145-146.

Svanborg, Eden, C., Eriksson, B., Hanson, L.A. 1977. Adhesion of Eschericha coli to human uroepithelial cells in vitro. Infect. Immun., 18: 767-774.

Savage, D.C. 1972. Survival on mucosal epithelia, epithelial penetration and growth of tissues of pathogenic bacteria. Symp. Soc. Gen. Microbiol., 22: 25-57.

Vosti, K.L. 1979. Relationship of hemagglutination to other biological properties of serologically classified isolates of Escherichia coli. Infect. Immun., 25: 507-512.

Warren, J.W. 1997. Host parasite interactions and host defence mechanisms, Chapter In: Diseases of the kidney. $6^{\text {th }}$ ed, Vol 1, Schrier RW, Gottschalk CW. Eds (Little Brown, London). 873-894.

Wullt, B. 2002. The role of P fimbiae for Escherichia coli establishment and mucosal inflammation in the human urinary tract. Int. J. Antimicrob. Agent, 21: 605-21.

Wardlaw, A.C. 1963. The complementdependent bacteriolytic activity of normal serum.II.Cell wall composition of sensitive and resistant strains. Canadian J. Microbiol., 9: 41-52.

Wiener, J., Qumn, J.P., Bradford, P.A., Goering, R.V., Nathan, C., Bush, K., et al. 1999. Multiple antibiotic resistant Klebsiellaand Escherichia coli in a nursing home. JAMA, 517-23.

Yasmeen Kausar, Sneha, K., Chunchanur, Shobha, D., Nadagir, et al. 2009. Virulence factors, Serotypes and Antimicrobial susceptibility pattern of Escherichia coli in Urinary tract infections. Al Ameen J. Med. Sci., 2(1): 47-51.

Zobell, C.E. 1943. The effect of solid surfaces on bacterial activity. $J$. Bacteriol., 46: 39-56.

\section{How to cite this article:}

Anuradha Bhrugubalda, Uma Penmetcha, Padmaja Yarlagadda and Ramesh Babu Myeneni. 2016. A Study of Virulence Factors and Drug Resistance Pattern in Escherichia coli Isolated from Extra Intestinal Infections in a Tertiary Care Teaching Hospital, Chinakakani, Guntur, Andhra Pradesh, South India. Int.J.Curr.Microbiol.App.Sci. 5(4): 140-158. doi: http://dx.doi.org/10.20546/ijcmas.2016.504.019 